\title{
EVALUATION AND IMPROVEMENT OF THE LEVEL OF SERVICE OF MULTI- LANE HIGHWAYS IN JORDAN
}

\section{Majed Msallam}

Professional paper/Stručni rad

(Received: 10 January 2019; accepted: 10 June 2019)

Al-Balqaa' Applied University, Faculty of Engineering Technology Amman, Jordan, Associate Professor

Corresponding author: majed.msallam@bau.edu.jo

\begin{abstract}
The study aims to analyze, evaluate, and improve the level of service (LOC) of multi-lane highways in Jordan. The Alhizam multi-lane rural highway in Jordan was selected as a case study as it is considered a major arterial highway with high traffic volume. The traffic data was collected from governmental records of different departments in the Ministry of Public Work and Housing during the summer period of 2015. HCS-2000 and HCS2010 software were used to evaluate the LOC for the existing, short-term (year 2020), and medium-term (year 2025) conditions. Some of the highway's segments operate at LOS-E or LOS-F for short-term and medium-term conditions. For these segments, the short-term or medium-term conditions were improved through the modification of geometric and traffic conditions so that the segments operate at LOS-C or LOS-D. Management flow diagrams were prepared to provide decision-makers with a useful tool for the planning of rural mult-lane highways in Jordan.
\end{abstract}

Keywords: multi-lane highways; highway capacity manual; highway capacity system; level of service; highway management

\section{OCJENA I POBOLJŠANJE RAZINE USLUGE VIŠETRAČNE AUTOCESTE U JORDANU}

Sažetak: Cilj istraživanja je analizirati, ocijeniti i poboljšati razinu usluge (LOC) na višetračnim autocestama u Jordanu. Višetračna ruralna autocesta Alhizam u Jordanu odabrana je za primjer jer se smatra glavnom magistralnom autocestom s velikim prometnim opterećenjem. Podatci o prometu prikupljeni su iz vladinih evidencija različith odjela u Ministarstvu javnih poslova i stanovanja tijekom ljetnog razdoblja 2015. godine. Računalni programi HCS-2000 i HCS-2010 korišteni su za procjenu LOC-a za postojeće, kratkoročne (2020. godina) i srednjoročne (godina 2025.) uvjete. Neki segmenti autocesta imaju razinu usluge $E$ ili $F$ za kratkoročne i srednjoročne uvjete. Za ove segmente, kratkoročni ili srednjoročni uvjeti poboljšani su modificiranjem geometrijskih i prometnih uvjeta kako bi imali razinu usluge $\mathrm{C}$ ili D. Izrađeni su dijagrami upravljanja kako bi se upraviteljima cesta pružio koristan alat za planiranje ruralnih višetračnih autocesta u Jordanu.

Ključne riječi: višetračne autoceste; priručnik za propusnu moć autoceste; sustav propusne moći autoceste; razina usluge; upravljanje autocestama 


\section{INTRODUCTION}

Roads and highways are a major part of transportation infrastructure in Jordan. They play a substantial role in the local economy and community development. Advancements in transportation play a critical part in sustainability and development in Jordan as well as other countries [1]. It is essential for these services to be of high quality to ensure safe and cost-effective daily traffic operations. Transportation availability and associated facilities affect the economic development and growth of a nation [2]. Good transportation facilities allow the development of commerce or industry by decreasing transportation costs for manufactured goods and raw materials between regions; this results in more choices and lower costs for consumers. Transportation is a necessary element of governmental services, playing an important role in the defense of a nation, mail delivery, and territory control $[3$, 4].

The rapid growth of the population in Jordan has led to increased usage of vehicles and highways. The transportation industry is a component of the service sector. It is important for traffic engineers and planners to understand and evaluate the quality of service provided by transport facilities. The highway capacity manual (HCM) is a pioneer document in this area. This document quantified the concept of capacity for a transport facility and laid the foundations for estimating the level of service (LOS) provided by a facility to its users. Future plans for highways in Jordan need to be developed to improve the quality of service, as the growing number of vehicles has led to a lower quality of service. Therefore, it is necessary to study the causes and find solutions.

The HCM is a pioneer document in managing and evaluating the capacity and quality of services for various highway facilities, including multi-lane highways. Five editions of HCM have published since 1950. The HCM-1950 was the first international document on the subject of capacity, providing definitions of key terms, a compilation of maximum observed traffic flows, and inifial fundamentals on capacity [5]. HCM-1965, the second edition, focused on determination of the capacity and service volume (or LOS) for new or existing highways under specified conditions [6]. The HCM-1985 document refined the concept of LOS and incorporated the results of several major research projects, conducted after the publication of HCM-1965 [7]. The HCS-2000 document provided a systematic basis to assess the capacity and LOS for elements of surface transportation systems that involve a series or combination of individual facilities [8]. The updated HCS-2010 document has been reorganized to make its contents more accessible and understandable. The reorganization intends to encourage decision-makers to consider all roadway users and a broader range of performance measurements, while assessing the performance of a transportation facility.

The HCM-2010 document defines multi-lane highways as a highway with two or three lanes in each direction and posted speed limits of 40 to $55 \mathrm{mi} / \mathrm{h}(60$ to $90 \mathrm{~km} / \mathrm{h})$, divided by a median or a two-way left-turn lane (TWLTL) [9]. It can also be undivided with no control or partial control of access, but with periodic interruptions to flow at signalized intersections no closer than $3 \mathrm{~km}$. The HCM-2010 methodology does not evaluate the LOC on freeways with free-flow speeds greater than $75 \mathrm{mi} / \mathrm{h}(120 \mathrm{~km} / \mathrm{h})$ or mult-lane highways with free-flow speeds greater than 60 $\mathrm{mi} / \mathrm{h}(90 \mathrm{~km} / \mathrm{h})$ [9]. Several states in USA now have highways with posted speed limits that exceed these free-flow speeds. The Texas A\&M Transportation Institute (TTI) developed speed-prediction equations for uninterrupted flow facilities with higher posted speed limits. It is recommended to use TTI speed prediction equations to calculate the base free-flow speed (BFFS). This value is then used to calculate free-flow speed (FFS) and determine LOC from speed-flow curves [10]. It re-evaluates the use of lateral clearance instead of shoulder width when calculating the free-flow speed and is capable of incorporating data sets with greater variations in lane width with higher posted speed limits.

Typically, multi-lane highways lead to the city center or function as high-volume rural corridors, connecting two cities or two activity centers. The Highway Capacity Software (HCS) [11] was originally created by the Federal Highway Administration (FHWA) in 1986 at the Center for Microcomputers in Transportation (McTrans). This center is now a full-service software support center associated with the University of Florida. HCS is a windows application with an extensive help system and a high level of professional technical support. HCS-2000 and HCS-2010 were developed to perform the procedures defined in HCM-2000 and HCM-2010 [12]. The main difference between HCM-2000 and HCM-2010 is that HCM-2010 is a modified version of HCM-2000. Some facilities are likely to experience differences in the predicted travel speed and LOC when comparing the methodologies in HCM-2000 and HCM-2010. The main aim of the software is to analyze the capacity and determine the LOS for signalized and

Msallam, M 
un-signalized intersections, urban streets (arterials), freeways, weaving areas, ramp junctions, mult-lane highways, and two-lane highways [13].

In [14], the speed-flow characteristics on several types of multilane highways, including four-lane, six-lane and eight-lane divided carriageways, in plain terrain in India were studied using collected data. Free-speed profiles and speed-flow equations for different vehicle types and varying widths of mult-lane highways in the country were developed. Traditional and microscopic simulation models were used to estimate the roadway capacity. The lanechange behavior of different vehicle types was studied, to evaluate its impact on roadway capacity on multi-lane highways. It has been observed that the mean free speeds of different vehicle types on eight-lane highways are higher when compared to those on four-lane and six-lane divided carriageways. The free speeds of two wheelers and cars marginally increase on six-lane highways compared to four-lane highways whereas the free speed of vehicles on six-lane highways are significantly higher than those on eight-lane highways. The free speeds of heavy vehicles and autos are significantly higher on six-lane highways compared to four-lane highways, and only marginally increase compared to those on eight-lane highways.

In [15], the relationship between the posted speed limit, operating speed, and other significant variables was determined using speed data collected from highways and rural freeways in Texas (four-lane and two-lane) to explain the effect of traffic characteristics and highway geometrics using $\mathrm{HCM}$ speed-prediction equations. It was observed that the light level (day versus night) is a significant variable for rural non-limited access roads, with nighttime speeds being slightly lower. Other significant variables identified in the work included the lane (inside or outside), horizontal curve characteristics downstream of the tangent section, and cross-section variables such as lane or shoulder width. Moreover, a significant difference in speed was found depending on whether the vehicle was in the inside or outside lane; this may influence, for example, 85th percentle speed studies. This means that speed studies can be conducted using data from the slower lane or mixed data from both lanes in four-lane highways; however, there are advantages and inconveniences for each approach.

\section{CASE STUDY}

The Alhizam highway, a divided multi-lane rural highway, was selected for investigation. This two-lane highway connects Amman and Alzarqa'a Industrial City as well as different public and private universities and north-east areas. The highway is also near the Marka civilian and military airport and many other industrial and commercial facilities. It suffers from serious congestion at different times of the day and has a high number of heavy trucks that transfer goods to and from the free zone in Alzarqa'a.

The northbound (NB) and the southbound (SB) traffic directions of the highway were divided into multiple segments based on the requirements of the HCM methodology. These requirements include a change in median treatment, a change in grade of $2 \%$ or more, or a constant upgrade over $0.76 \mathrm{mi}(1.22 \mathrm{~km})$. Other requirements are a change in number of travel lanes, presence of traffic signal, significant change in density of access points, different speed limits, and presence of botteneck conditions. Six segments that meet these requirements were selected from the highway to be evaluated, as shown in Figure 1. All the lanes in the Alhizam highway are shown in Figure 2.

Msallam, M 


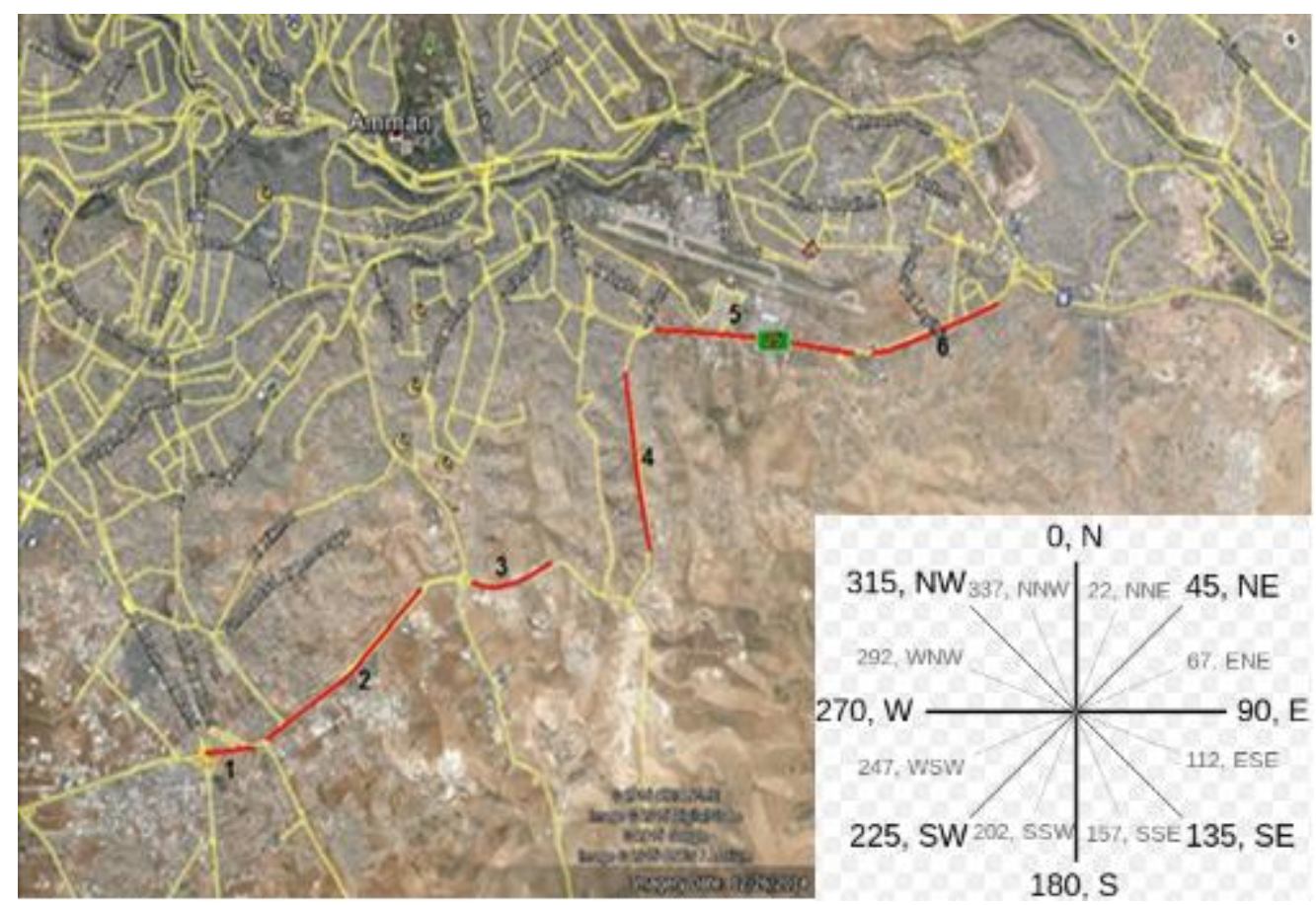

Figure 1 Aerial Photograph (Screen Shot) of Selected Segments on the Alhizam Highway (Google Earth Program)
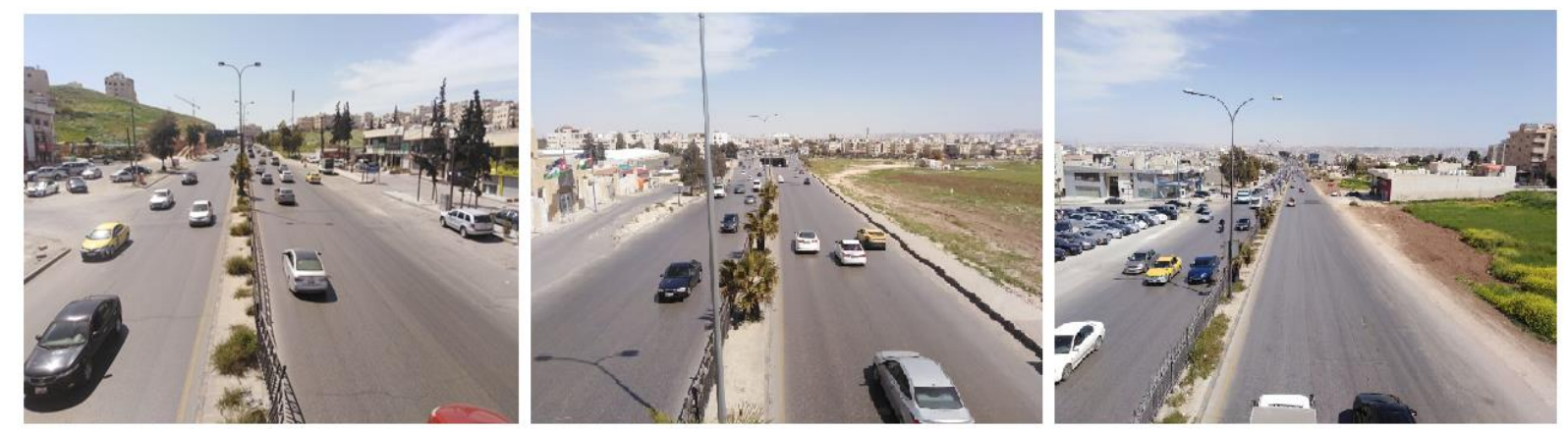

Figure 2 Lanes of Alhizam Highway (Panoramic view)

\subsection{Data Collection}

A field investigation was conducted to check the geometric and traffic data of the highway and define the six segments; any additional data required for the analysis were also collected. For any data that could not be collected, the ideal condition and default values recommended by HCM were used, for example, driver population factor and peak hour factor (PHF). The highways are classified as rural multi-lane highways, which fall within the responsibility of the Ministry of Public Works and Housing (MPWH). Therefore, government records are considered the most dependable source of the required data. The data used in this study contained road geometric data, traffic volume data, and vehicle speed data, obtained from several ministry departments (Department of Geographic Information Systems (GIS), Department of Road Studies, and Traffic Department)

The demand volume under prevailing conditions (V) for the selected segments must be estimated and converted to the demand flow rate under equivalent base conditions $(\mathrm{VP})$ to define the LOS for each segment. The maximum peak hour volumes (PHV) for each segment were obtained from traffic counters distributed by the MPWH. In recent years, the traffic volume in Jordan highways i.e., the number of vehicles, has increased with a yearly growth rate $(\mathrm{g})$ of $6.57 \%$. The posted speed limits were determined for each segment. The BFFS was estimated from the posted speed limit. According to HCM-2010, the BFFS on multi-lane highways under base conditions is approximately the posted speed plus $5 \mathrm{mi} / \mathrm{h}(8 \mathrm{~km} / \mathrm{h})$ for speeds of $50 \mathrm{mi} / \mathrm{h}(80 \mathrm{~km} / \mathrm{h})$ and higher. For speeds lower than $50 \mathrm{mi} / \mathrm{h}(80 \mathrm{~km} / \mathrm{h})$, the BFFS is the posted speed plus $7 \mathrm{mi} / \mathrm{h}(11 \mathrm{~km} / \mathrm{h})$.

\section{Msallam, M}


Based on the Jordanian code of highways, the left side of the highway is for NB traffic and the right side of the highway is for SB traffic. Therefore, all the access points have an L-exit sign in the north direction and a R-exit sign in the south direction. The geometric and volume input data for each segment in each direction of the selected highway were organized for existing conditions in year 2015, as shown in Table 1. Table 1 shows the length for each segment, PHV, percent of grade (terrain), percent of heavy vehicle, density of access points (AP/km), posted speed limit, and lane width (LW). The PHV is constant, based on the methodology defined in the Highway Capacity Manual. The data in Table 1 needs to be converted for future analysis according to the growth rate $(6.57 \%)$. Therefore, the forecasted values were estimated for a short-term period, corresponding to the next 5 years (year 2020), and for the medium-term period, corresponding to the next 10 years (year 2025), as shown in Table 2 and Table 3, respectively.

Table 1 Traffic and geometric data of each segment on Alhizam highway (Existing conditions - year 2015)

\begin{tabular}{|c|c|c|c|c|c|c|c|c|}
\hline \multicolumn{9}{|c|}{$\begin{array}{l}\text { Alhizam highway } \\
\text { Left side (NB) }\end{array}$} \\
\hline $\begin{array}{l}\text { Seg. } \\
\text { No. }\end{array}$ & $\begin{array}{l}\text { Length } \\
(\mathrm{km})\end{array}$ & $\begin{array}{c}\text { PHV } \\
\text { (veh/h) }\end{array}$ & \multicolumn{2}{|c|}{$\begin{array}{c}\text { Percent of Grade } \\
(\%)\end{array}$} & HV \% & $\begin{array}{l}\text { Access Points } \\
\text { (AP/ km) }\end{array}$ & $\begin{array}{c}\text { Posted Speed } \\
(\mathrm{km} / \mathrm{h})\end{array}$ & $\begin{array}{l}\text { Lane Width } \\
\text { (m) }\end{array}$ \\
\hline 1 & 0.64 & 1631 & 7.60 & Upgrade & 13.5 & 8.05 & 80 & 3.3 \\
\hline 2 & 2.63 & 1631 & 2.10 & Downgrade & 13.5 & 6.44 & 80 & 3.6 \\
\hline 3 & 1.10 & 1631 & 3.00 & Upgrade & 13.5 & 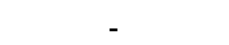 & 80 & 3.6 \\
\hline 4 & 2.04 & 1631 & 2.70 & Downgrade & 13.5 & 1.61 & 80 & 3.6 \\
\hline 5 & 2.63 & 1631 & 1.40 & Level & 13.5 & 4.83 & 80 & 3.3 \\
\hline 6 & 1.78 & 1631 & 2.73 & Upgrade & 13.5 & 4.83 & 80 & 3.3 \\
\hline \multicolumn{9}{|c|}{ Right side (SB) } \\
\hline $\begin{array}{l}\text { Seg. } \\
\text { No. }\end{array}$ & $\begin{array}{l}\text { Length } \\
(\mathbf{k m})\end{array}$ & $\begin{array}{c}\mathrm{PHV} \\
\text { (veh/h) }\end{array}$ & \multicolumn{2}{|c|}{$\begin{array}{l}\text { Percent of Grade } \\
(\%)\end{array}$} & HV \% & $\begin{array}{l}\text { Access Points } \\
(\mathrm{AP} / \mathrm{km})\end{array}$ & $\begin{array}{l}\text { Posted Speed } \\
(\mathrm{km} / \mathrm{h})\end{array}$ & $\begin{array}{l}\text { Lane Width } \\
\text { (m) }\end{array}$ \\
\hline 1 & 0.64 & 2392 & 7.60 & Downgrade & 16.2 & 3.22 & 80 & 3.3 \\
\hline 2 & 2.63 & 2392 & 2.10 & Upgrade & 16.2 & 4.83 & 80 & 3.6 \\
\hline 3 & 1.10 & 2392 & 3.00 & Downgrade & 16.2 & 4.83 & 80 & 3.6 \\
\hline 4 & 2.04 & 2392 & 2.70 & Upgrade & 16.2 & 6.44 & 80 & 3.6 \\
\hline 5 & 2.63 & 2392 & 1.40 & Level & 16.2 & 3.83 & 80 & 3.3 \\
\hline 6 & 1.78 & 2392 & 2.73 & Downgrade & 16.2 & 3.83 & 80 & 3.3 \\
\hline
\end{tabular}

Table 2 Traffic and geometric data of each segment for Alhizam highway (Short term - year 2020)

\begin{tabular}{|c|c|c|c|c|c|c|c|c|}
\hline \multicolumn{9}{|c|}{$\begin{array}{l}\text { Alhizam highway } \\
\text { Left side (NB) }\end{array}$} \\
\hline $\begin{array}{l}\text { Seg. } \\
\text { No. }\end{array}$ & $\begin{array}{l}\text { Length } \\
(\mathrm{km})\end{array}$ & $\begin{array}{c}\text { PHV } \\
\text { (veh/h) }\end{array}$ & \multicolumn{2}{|c|}{$\begin{array}{l}\text { Percent of Grade } \\
(\%)\end{array}$} & HV \% & $\begin{array}{l}\text { Access Points } \\
(\mathrm{AP} / \mathrm{km})\end{array}$ & $\begin{array}{l}\text { Posted Speed } \\
(\mathrm{km} / \mathrm{h})\end{array}$ & $\begin{array}{l}\text { Lane Width } \\
\text { (m) }\end{array}$ \\
\hline 1 & 0.64 & 2242 & 7.6 & Upgrade & 18.56 & 8.0 & 80 & 10.0 \\
\hline 2 & 2.63 & 2242 & 2.10 & Downgrade & 18.56 & 6.4 & 80 & 11.5 \\
\hline 3 & 1.10 & 2242 & 3.00 & Upgrade & 18.56 & - & 80 & 11.5 \\
\hline 4 & 2.04 & 2242 & 2.70 & Downgrade & 18.56 & 1.6 & 80 & 11.5 \\
\hline 5 & 2.63 & 2242 & 1.40 & Level & 18.56 & 4.8 & 80 & 10.0 \\
\hline \multirow{2}{*}{\multicolumn{9}{|c|}{ Right side (SB) }} \\
\hline & & & & & & & & \\
\hline $\begin{array}{l}\text { Seg. } \\
\text { No. }\end{array}$ & $\begin{array}{l}\text { Length } \\
(\mathrm{km})\end{array}$ & $\begin{array}{l}\text { PHV } \\
\text { (veh/h) }\end{array}$ & Perc & $\begin{array}{l}\text { nt of Grade } \\
(\%)\end{array}$ & HV \% & $\begin{array}{l}\text { Access Points } \\
(\text { AP/ km) }\end{array}$ & $\begin{array}{l}\text { Posted Speed } \\
(\mathrm{km} / \mathrm{h})\end{array}$ & $\begin{array}{l}\text { Lane Width } \\
\text { (m) }\end{array}$ \\
\hline 1 & 0.64 & 3289 & 7.60 & Downgrade & 22.28 & 3.22 & 80 & 10.0 \\
\hline 2 & 2.63 & 3289 & 2.10 & Upgrade & 22.28 & 4.83 & 80 & 11.5 \\
\hline 3 & 1.10 & 3289 & 3.00 & Downgrade & 22.28 & 4.83 & 80 & 11.5 \\
\hline 4 & 2.04 & 3289 & 2.70 & Upgrade & 22.28 & 6.44 & 80 & 11.5 \\
\hline 5 & 2.63 & 3289 & 1.40 & Level & 22.28 & 3.83 & 80 & 10.0 \\
\hline 6 & 1.78 & 3289 & 2.73 & Downgrade & 22.28 & 3.8 & 80 & 10.0 \\
\hline
\end{tabular}

Msallam, M 
Table 3 Traffic and geometric data of each segment for Alhizam highway (Medium term - year 2025)

\begin{tabular}{|c|c|c|c|c|c|c|c|c|}
\hline \multirow[b]{2}{*}{$\begin{array}{l}\text { Seg. } \\
\text { No. }\end{array}$} & \multirow[b]{2}{*}{$\begin{array}{l}\text { Length } \\
(\mathrm{km})\end{array}$} & \multicolumn{6}{|c|}{ Left side (NB) } & \multirow[b]{2}{*}{$\begin{array}{l}\text { Lane Width } \\
(\mathrm{m})\end{array}$} \\
\hline & & $\begin{array}{c}\text { PHV } \\
\text { (veh/h) }\end{array}$ & \multicolumn{2}{|c|}{$\begin{array}{c}\text { Percent of Grade } \\
(\%)\end{array}$} & HV \% & $\begin{array}{l}\text { Access Points } \\
\text { AP/ km }\end{array}$ & $\begin{array}{l}\text { Posted Speed } \\
(\mathrm{km} / \mathrm{h})\end{array}$ & \\
\hline 1 & 0.64 & 3080 & 7.6 & Upgrade & 25.56 & 3.3 & 80 & 10.0 \\
\hline 2 & 2.63 & 3080 & 2.10 & Downgrade & 25.56 & 3.6 & 80 & 11.5 \\
\hline 3 & 1.10 & 3080 & 3.00 & Upgrade & 25.56 & 3.6 & 80 & 11.5 \\
\hline 4 & 2.04 & 3080 & 2.70 & Downgrade & 25.56 & 3.6 & 80 & 11.5 \\
\hline 5 & 2.63 & 3080 & 1.40 & Level & 25.56 & 3.3 & 80 & 10.0 \\
\hline 6 & 1.78 & 3080 & 2.73 & Upgrade & 25.56 & 3.3 & 80 & 10.0 \\
\hline \multicolumn{9}{|c|}{ Right side (SB) } \\
\hline $\begin{array}{l}\text { Seg. } \\
\text { No. }\end{array}$ & $\begin{array}{l}\text { Length } \\
(\mathrm{km})\end{array}$ & $\begin{array}{c}\mathrm{PHV} \\
\text { (veh/h) }\end{array}$ & \multicolumn{2}{|c|}{$\begin{array}{c}\text { Percent of Grade } \\
(\%)\end{array}$} & HV \% & $\begin{array}{c}\text { Access Points } \\
\text { AP/ km }\end{array}$ & $\begin{array}{c}\text { Posted Speed } \\
(\mathrm{km} / \mathrm{h})\end{array}$ & $\begin{array}{c}\text { Lane Width } \\
(\mathrm{m})\end{array}$ \\
\hline 1 & 0.64 & 4518 & 7.60 & Downgrade & 30.78 & 3.3 & 80 & 10.0 \\
\hline 2 & 2.63 & 4518 & 2.10 & Upgrade & 30.78 & 3.6 & 80 & 11.5 \\
\hline 3 & 1.10 & 4518 & 3.00 & Downgrade & 30.78 & 3.6 & 80 & 11.5 \\
\hline 4 & 2.04 & 4518 & 2.70 & Upgrade & 30.78 & 3.6 & 80 & 11.5 \\
\hline 5 & 2.63 & 4518 & 1.40 & Level & 30.78 & 3.3 & 80 & 10.0 \\
\hline 6 & 1.78 & 4518 & 2.73 & Downgrade & 30.78 & 3.3 & 80 & 10.0 \\
\hline
\end{tabular}

\section{RESULTS AND DISCUSSION}

In this study, the existing traffic conditions of the selected highway were used to determine the LOS expected in the next five years (short-term evaluation i.e., 2020) and ten years (medium-term evaluation i.e., 2025). According to the Policy on Geometric Design of Highway and Street [12], an acceptable LOS for rural highways is LOS-C (stable flow). However, a lower LOS, such as LOS-D (approaching unstable flow), is acceptable for some highway agencies. LOS-E (unstable flow or maximum capacity) and LOS $-\mathrm{F}$ (forced or breakdown flow) are not acceptable traffic conditions; in these cases, the highway segments should be improved to have a better LOS [12].

It is important for the decision makers to determine the possibility of improvement of each segment based on the HCM-2000 and updated HCM-2010 methodologies [9]. The HCS-2000 and HCS-2010 computer program was used for the comparison and validation of the results for each selected segment to develop a more accurate management and improvement program [8]. Each segment was analyzed using both programs for existing, shortterm, and medium-term conditions, for both the right (SB) and left (NB) directions $[8,9]$. The results are presented in Table 4.

Table 4 Comparison of results obtained via HCS 2000 and HCS 2010 for Alhizam highway segments for existing, short-term, and medium-term conditions

\begin{tabular}{|c|c|c|c|c|c|c|c|c|c|c|}
\hline \multicolumn{11}{|c|}{ Results for existing conditions - year 2015} \\
\hline \multirow{2}{*}{$\begin{array}{l}\text { Seg. } \\
\text { No. }\end{array}$} & \multirow[t]{2}{*}{ Dir. } & \multirow{2}{*}{$\begin{array}{l}\text { Flow } \\
\text { Rate } \\
(\mathrm{pc} / \mathrm{h} / \mathrm{l})\end{array}$} & \multicolumn{4}{|c|}{ HCS 2000} & \multicolumn{4}{|c|}{ HCS 2010} \\
\hline & & & $\begin{array}{c}\mathrm{FFS} \\
(\mathrm{km} / \mathrm{h})\end{array}$ & $\begin{array}{l}\text { Avg. Travel Speed } \\
(\mathrm{km} / \mathrm{h})\end{array}$ & $\begin{array}{c}\text { Density } \\
\text { (pc/km/ln) }\end{array}$ & LOS & $\begin{array}{c}\text { FFS } \\
(\mathrm{km} / \mathrm{h})\end{array}$ & $\begin{array}{l}\text { Avg. Travel Speed } \\
(\mathrm{km} / \mathrm{h})\end{array}$ & $\begin{array}{c}\text { Density } \\
(\mathrm{pc} / \mathrm{km} / \mathrm{ln})\end{array}$ & LOS \\
\hline \multirow[t]{2}{*}{1} & Right & 756 & 75 & 75 & 10 & $B$ & 76 & 72 & 10 & $B$ \\
\hline & left & 983 & 76 & 76 & 13 & C & 77 & 81 & 12 & C \\
\hline \multirow[t]{2}{*}{2} & right & 991 & 85 & 85 & 12 & C & 84 & 81 & 12 & C \\
\hline & left & 1590 & 86 & 84 & 19 & D & 84 & 79 & 20 & D \\
\hline \multirow[t]{2}{*}{3} & right & 991 & 87 & 87 & 11 & C & 85 & 89 & 11 & C \\
\hline & left & 1474 & 86 & 85 & 17 & D & 84 & 80 & 18 & D \\
\hline \multirow[t]{2}{*}{4} & right & 991 & 86 & 86 & 12 & C & 85 & 89 & 11 & C \\
\hline & left & 1590 & 85 & 84 & 19 & D & 84 & 79 & 20 & D \\
\hline \multirow[t]{2}{*}{5} & right & 991 & 75 & 75 & 13 & C & 77 & 81 & 12 & C \\
\hline & left & 1474 & 75 & 75 & 20 & D & 77 & 80 & 18 & D \\
\hline \multirow[t]{2}{*}{6} & right & 1056 & 75 & 75 & 14 & C & 77 & 81 & 13 & C \\
\hline & left & 1474 & 75 & 75 & 20 & D & 77 & 80 & 18 & D \\
\hline
\end{tabular}

Msallam, M 


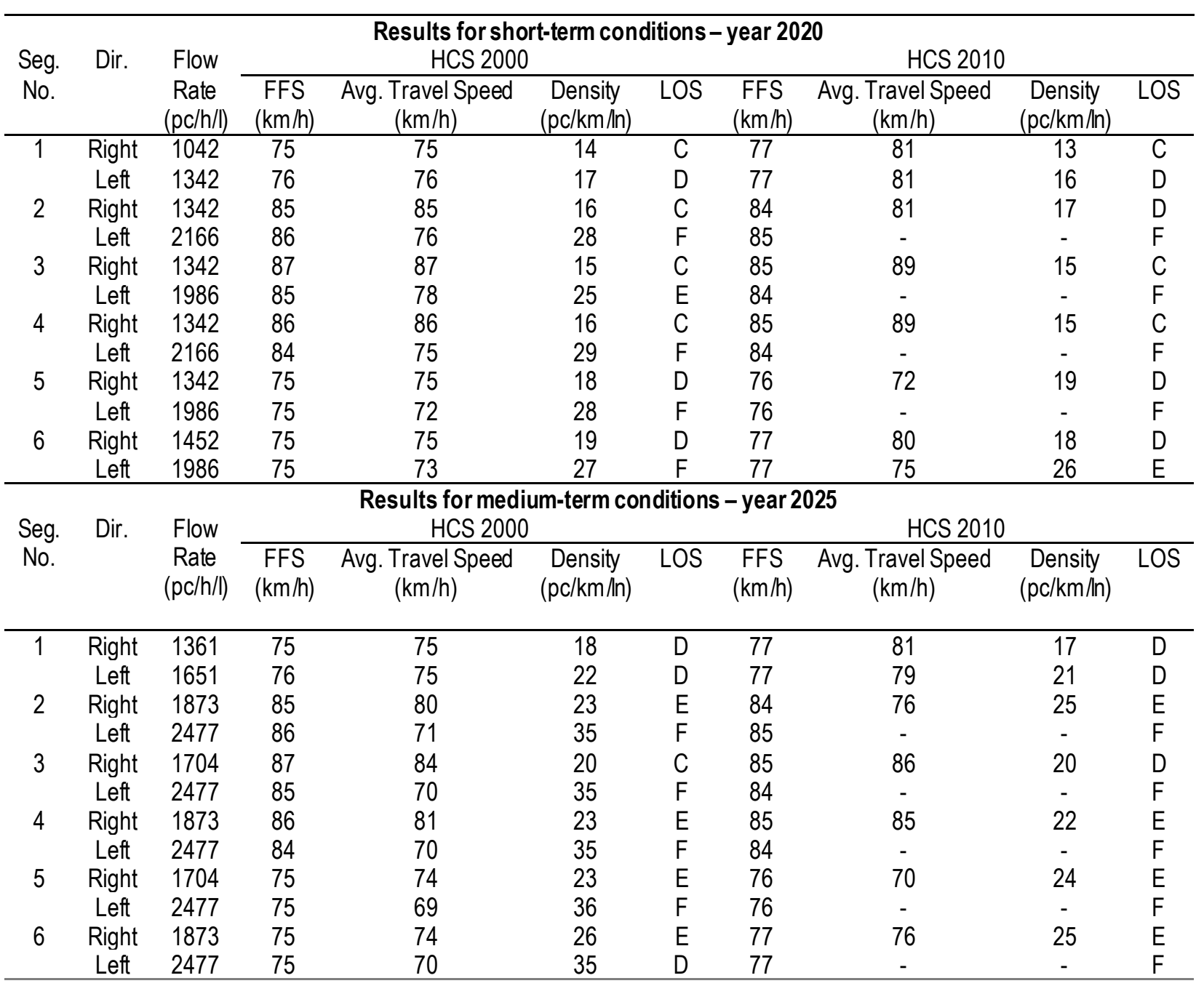

The analysis of the selected highway shows that some segments will operate in short-term and medium-term at LOS-F or at LOS-E. To improve the LOS of these segments; the following suggestions can be applied:

1- Increase the lane width for segments where the lane width is lower than $3.6 \mathrm{~m}$.

2- Increase the number of lanes from two lanes in each direction to three lanes in each direction.

3- Improve the geometric condition of segments i.e., construct segments with ideal geometric conditions, in order to increase the FFS.

The capacity for a specific freeway section is determined on the basis of the relationship between the speed and flow rate. Therefore, highways are constructed in such a way that they are capable of accommodating relatively large numbers of vehicles at higher speeds than other roadways.

The tables show that segments operating at LOS-E and LOS-F could be improved to have better LOS. Table 5 shows the output results for short- and medium-term periods after improving different segments. Segment 2 will operate at LOS-C and LOS-D after improvement, which are acceptable for both directions. Segment 3 shows a LOS between LOS-C and LOS-D after improvement, which are acceptable for both directions. The output results of the improvement of segment 4 show that the segment will operate at LOS-C for the short-term period and at LOS-D for the medium-term period, which is considered an acceptable LOS for both directions. The output results of the improvement for segment 5 results in operations at LOS-D for both periods and in both directions. 
Evaluation and improvement in the level of service of multi-lane highways in Jordan

Table 5 Output results for improvement for segments from Alhizam highway for short-term and medium-term conditions

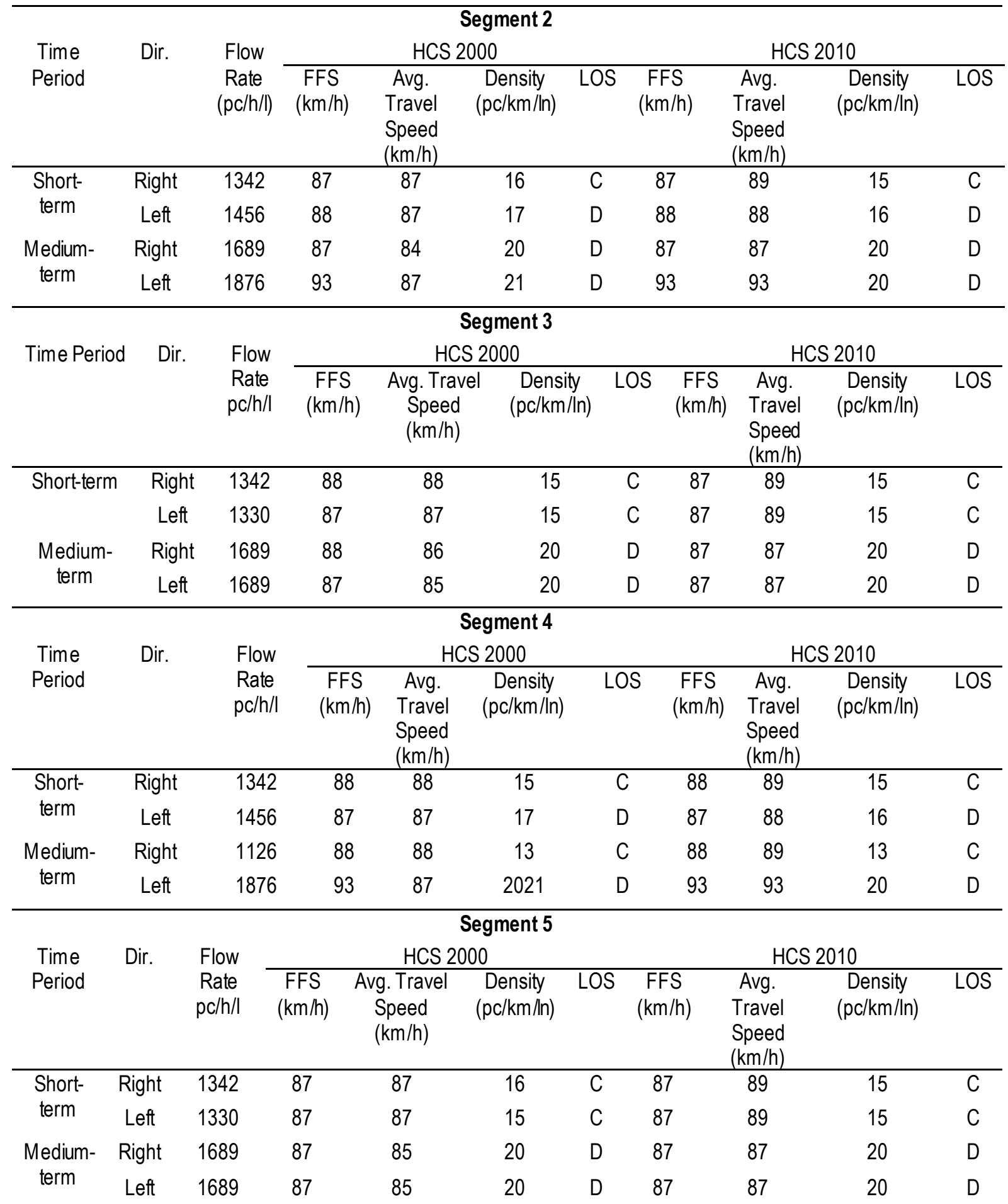

Msallam, M 
Evaluation and improvement in the level of service of multi-lane highways in Jordan

\begin{tabular}{|c|c|c|c|c|c|c|c|c|c|c|}
\hline \multirow{2}{*}{$\begin{array}{l}\text { Time } \\
\text { Period }\end{array}$} & \multirow[t]{2}{*}{ Dir. } & \multirow{2}{*}{$\begin{array}{c}\text { Flow Rate } \\
\mathrm{pc} / \mathrm{h} / \mathrm{l}\end{array}$} & \multicolumn{4}{|c|}{$\begin{array}{l}\text { Segment } 6 \\
\text { HCS } 2000\end{array}$} & \multicolumn{4}{|c|}{ HCS 2010} \\
\hline & & & $\begin{array}{l}\text { FFS } \\
(\mathrm{km} / \mathrm{h})\end{array}$ & $\begin{array}{c}\text { Avg. } \\
\text { Travel } \\
\text { Speed } \\
(\mathrm{km} / \mathrm{h})\end{array}$ & $\begin{array}{c}\text { Density } \\
(\mathrm{pc} / \mathrm{km} / \mathrm{ln})\end{array}$ & LOS & $\begin{array}{l}\text { FFS } \\
(\mathrm{km} / \mathrm{h})\end{array}$ & $\begin{array}{c}\text { Avg. } \\
\text { Travel } \\
\text { Speed } \\
(\mathrm{km} / \mathrm{h})\end{array}$ & $\begin{array}{c}\text { Density } \\
(\mathrm{pc} / \mathrm{km} / \mathrm{ln})\end{array}$ & LOS \\
\hline \multirow{4}{*}{$\begin{array}{c}\text { Short- } \\
\text { term } \\
\text { Medium- } \\
\text { term }\end{array}$} & Right & 1342 & 87 & 87 & 5 & $C$ & 87 & 89 & 15 & $C$ \\
\hline & Left & 1456 & 87 & 87 & 17 & D & 87 & 88 & 16 & D \\
\hline & Right & 1689 & 87 & 85 & 20 & D & 87 & 87 & 20 & D \\
\hline & Left & 1876 & 93 & 87 & 19 & D & 100 & 93 & 20 & D \\
\hline
\end{tabular}

The main goal of the present study was to improve the quality of service for selected segments of the Alhizam mult-lane highway. This improvement involves posting the speed limit to the maximum safe speed. It also includes eliminating the number of access points, increasing lane width, and increase the number of lanes to decrease the density; as a result, segments that operate low LOS (LOS-F or LOS-E) are improved to have a better LOS (LOSC or LOS-D). This improvement can decrease congestion, delay time, pollution, and stop time, increase safety for drivers, and result in better travel time. The cost estimation of this improvement is out of the scope of this study and hence, further studies are recommended. The management flow diagram was developed for the existing, shortterm and medium-term planning for the six segments of the selected Alhizam mult-lane highways. This was evaluated based on the analysis, evaluation, and improvement results obtained via the HCS-2000 and HCS 2010 computer programs and is shown in Figure 3. This diagram can assist decision-makers to determine the breakdown traffic conditions for segments that operate at LOS-F or operate at maximum capacity (LOS-E) during peak-hour periods and improve the LOS for short-term (2020) or medium-term (2025) conditions.

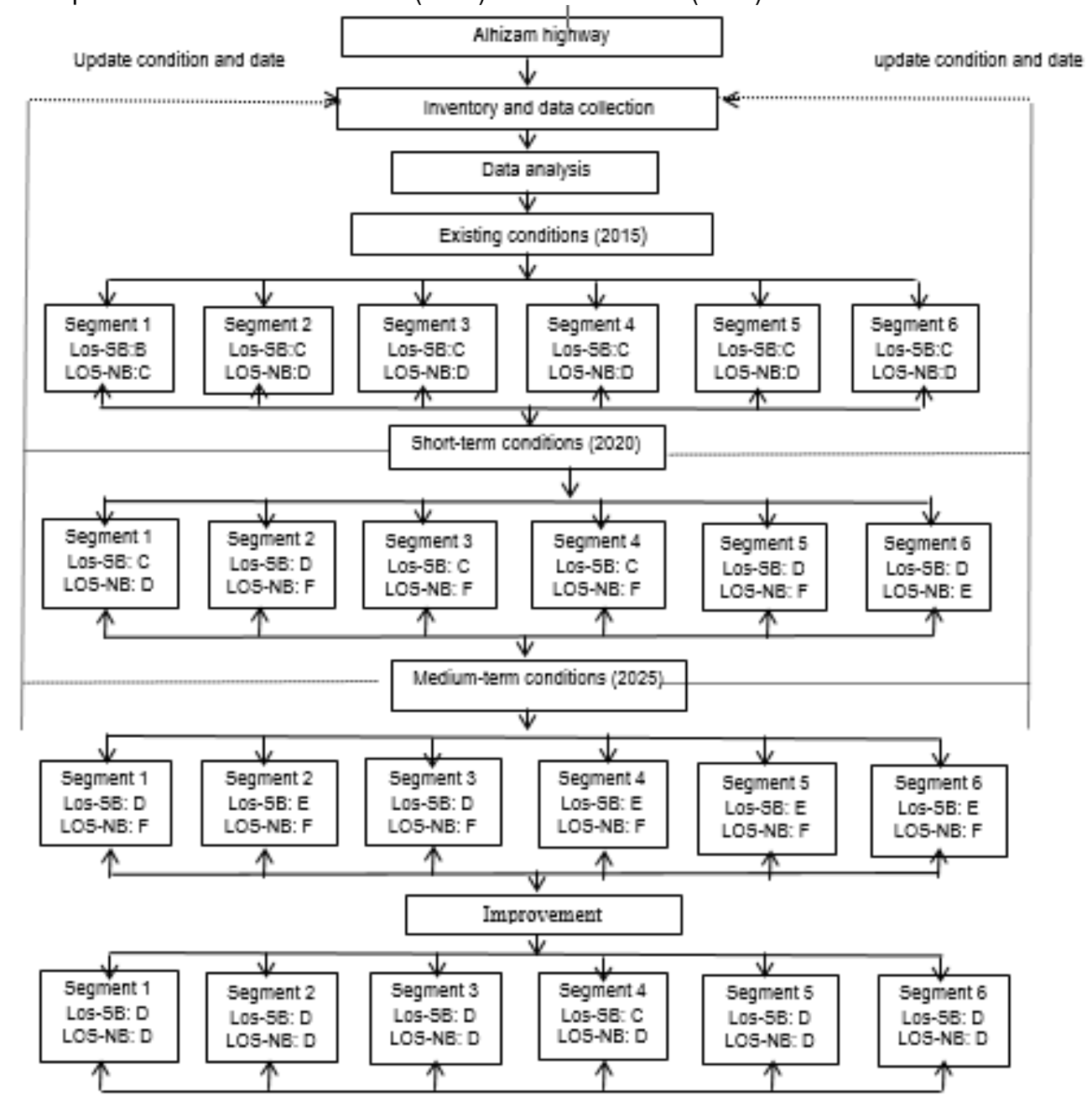

Figure 3 Flow Diagram of Management Components for Alhizam Highway Segments

Msallam, M 


\section{CONCLUSION}

The study used HCM-2000 and the updated HCM-2010 software for comparison and validation of output results. The results show no significant differences between HCM-2000 and updated HCM-2010 for the analysis and improvement of a multi-lane highway. The existing conditions of the selected highway all currently operate at LOS$B$ and LOS-D. The short-term and medium-term planning showed that segments 2, 3, 4, 5, and 6 for northbound directions (NB) will operate at LOS-F. Due to the improvement of the management program, all segments will operate at LOS-D and LOS-C. The improvement in LOS for the previous segments that currently operate at LOS$\mathrm{E}$ or LOS-F were due to modifying geometric and traffic conditions such as increasing the width of the segment's lane, increasing the number of lanes in each direction to three lanes, increasing the posted speed limit in order to decrease the density, and upgrading the prevailing geometric conditions to ideal geometric conditions. The developed flow diagram for the management of the Alhizam rural multi-lane highway will assist decision-makers in improving the LOS.

It is recommended to use the methodology presented in HCM 2010 for all major rural and suburban highways in Jordan in terms of operational analysis, design, and planning. Increasing the number of lanes and lane width and upgrading the geometic conditions to ideal geometric conditions have been recommended in the proposed improvement plan, especially for segments that are currently operating at LOS-E or LOS-F in Jordan. The economic analysis is out of the scope of this study but is recommended for future works. Maintaining and building a historical database, including traffic volume data and geometric data, for all major rural highways in Jordan is recommended. Long-term studies (15-20 years) in terms of capacity and LOS are essential for all rural multi-lane highways in Jordan; it may be required to change the class of some highways from a multi-lane highway to a freeway or expressway (full control of access) if the required funds are available. Future studies should focus on passing lanes or climbing lanes for specific segments on multi-lane highways. More studies on other major multi-lane highways in Jordan are also required.

\section{References}

[1] Alkheder, S.A. 2016: Transportation and tourism sustainability in major Jordanian tourism cities,Tourism Planning \& Development, 13(3), pp. 253-73, https://doi.org/10.1080/21568316.2015.1074098

[2] Garber, N.J.; Hoel, L.A. 2014: Traffic and highway engineering, Cengage Learning.

[3] Frolova, E.V.; Vinichenko, M.V.; Kirillov, A.V.; Rogach, O.V.; Kabanova, E.E. 2016: Development of social infrastructure in the management practices of local authorities: Trends and factors, International Journal of Environmental and Science Education, 11(15), pp. 7421-30.

[4] Liman, T. 2019: Evaluating Transportation Land Use Impacts: Considering the impacts, benefits and costs of different land use development patterns, Victoria Transport Policy Institute, https://www.vtpi.org/landuse.pdf, Accessed 16 June 2019

[5] Highway Capacity Manual (HCM), 1950: Practical Application of Research, Bureau of Public Road, Washington, D.C.

[6] Highway Capacity Manual (HCM), 1965: Highway Research Board, National Research Council, Washington, D.C.

[7] Highway Capacity Manual (HCM), 1985: Transportation Research Board (TRB), National Research Council, Washington, D.C.

[8] Highway Capacity Software (HCS), 2000: McTrans Center, University of Florida, The Traffic Software Integrated System (TSIS)

[9] Manual-HCM, H.C., 2010: Transportation Research Board. National Research

[10] Robertson, J.; Fitzpatrick, K.; Park, E.; Iragavarapu, V. 2014: Determining level of service on freeways and multiane highways with higher speeds, Transportation Research Record: Journal of the Transportation Research Board, 2461, pp. 85-93. https://doi.org/10.3141/2461-11

[11] Highway Capacity Manual (HCM), 2000: Transportation Research Board (TRB), National Research Council, Washington, D.C.

[12] Ensley J.O. 2012: Application of Highway Capacity Manual 2010 level-of-service methodologies for planning deficiency analysis, Master's Thesis, University of Tennessee

Msallam, M 
[13] American Association of State Highway and Transportation Officials (AASHTO), 2011: A policy on geometric design of highways and streets, AASHTO

[14] Velmurugan, S.; Errampalli, M.; Ravinder, K.; Sitaramanjaneyulu, K.; Gangopadhyay, S. 2010: Critical evaluation of roadway capacity of multi-lane high speed corridors under heterogeneous traffic conditions through traditional and microscopic simulation models, Journal of Indian Roads Congress, 71(3), pp. 235-64

[15] Fizpatrick, K. et al. 2012: Modeling operating speed using traffic, posted speed limit, and geometric characteristics, TRB 2013 Annual Meeting.

Please cite this article as:

Msallam, M.: Evaluation and improvement in the level of service of multi-lane highways in Jordan, Electronic Journal of the Faculty of Civil Engineering Osijek-e-GFOS, 2019, 18, pp. 71-81, https://doi.org/10.13167/2019.18.7

Msallam, M 